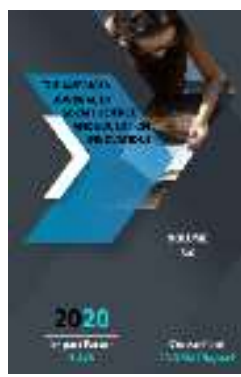

\title{
The Younger Generation Is A Force For The Future Of Our National Development
}

\author{
Dilorom Murotova \\ Executive Secretary Of The Writers' Union Of Uzbekistan In The Joint Editorial Board of \\ "Sharq Yulduzi" And “Zvezda Vostoka" Magazines, Uzbekistan
}

\begin{abstract}
Journal Website: http://usajournalshub.c om/index,php/tajssei

Copyright: Original content from this work may be used under the terms of the creative commons attributes 4.0 licence.
\end{abstract}

\section{ABSTRACT}

The article focuses on the issue of upbringing of young people at a time when "struggles" of various forms and content have a negative impact on their minds, and the functionality of upbringing is studied in relation to the childhood history of mankind. The researcher conducted an empirical study on the topic and made a comparative analysis of it. Citing a comparative interpretation of parents 'attitudes toward parenting methods, several reasons for this improvement are outlined.

\section{KEYWORDS}

Upbringing, strategic task, national interest, individual deviation, childhood history, infanticide, ambivalence, bonding method, socialization method, supportive method, upbringing tasks.

\section{INTRODUCTION}

A self-aware person demonstrates his knowledge and talent in this way, knowing from a spiritual and moral point of view that he is responsible for the bright future of his homeland, ensuring the peace of his loved ones. Because "only in times of crisis can a truly spiritual and enlightened person knows human dignity, understands his national values, national identity, lives in a free and prosperous society, and selflessly fights for our independent state to take its rightful place in the world community" $[3,16]$. The role of the family and parents in educating the younger generation in this spirit is invaluable. After all, the child's first impressions of the environment are formed by them in infancy. Therefore, the rights and obligations of parents are clearly stated in Articles $63,64,65$ of the Constitution of the country and the obligations of children to their parents in Article 66 [13, 21-22]. 
Parenting is an issue that has acquired a high social content that is extremely complex, delicate, and requires constant attention. Parents are interested in the physical and spiritual development of their children. To do this, they need to be able to deeply understand the behavior and inner world of each child, to understand any problem correctly and be ready to respond in a timely manner. After all, in the family is brought up the successor of his generation, the future of the nation, the young generation that will ensure the development of the homeland.

A comprehensive approach to the education of the younger generation is needed so that they are not exposed to negative (destructive) ideas and information. Because the protection of our youth from such negative situations, the proper development is one of the tasks, such as ensuring the future of the nation and the homeland. It is obvious that in carrying out this task, which has acquired a strategic content, it is necessary to take into account the practical content of such important features as historical, scientific, sectoral, relevance and nationality (protection of national interests). Therefore, it is expedient to approach this issue as a system of "Human - Society - State" and "Human - Environment". This, in turn, requires educational activities based on the idea that "the younger generation - the force that ensures the prospects of our national development". In order to ensure the comprehensiveness of this issue, it is necessary to consider several issues in conjunction. Because, as Tatyana Simonenko points out, “... to understand the essence of any event (process - D.M.) it is not enough to know it objectively. Maybe you need to go inside the object and study it" [12]. Therefore, we aimed to explore several aspects of the selected topic, taking into account the level of relevance. Including:

- As a first step, to determine the historical stages of education and its content;
- As a second aspect, to carry out a pairwise comparison of the concluding part of the empirical research;

- As a third aspect, selecting a specific area of education and interpreting existing ideas;

- As a fourth aspect, to determine the importance of the problem selected for the analysis;

- As a fifth aspect, it is necessary to determine the protection of national interests in the field of education, in particular, its current and future status (forecast).

This approach can serve as a theoretical basis for defining a mechanism to protect young people from destructive ideas and negative information.

\section{MATERIALS AND METHODS}

At a time when "struggles" of various forms and content are taking place in order to negatively affect the minds of young people, their upbringing is characterized by personal spirituality, national way of life, attitude to the environment and relatives, as well as objects, indifference to national traditions, values and history. "To inculcate the spirit of cultural life in the attention of the younger generation in a variety of ways (demonstration, leadership, persuasion, direction, guidance, etc.) and tools (virtual friends and love, online games that promote aggressive behavior, etc.) with the help of destructive ideas and flawed information.

As a result of their influence, different deviations can manifest themselves individually and in groups. Although theoretically in social philosophy and sociology [11] the deviations are divided into culturally acceptable and culturally unacceptable types for the benefit or harm of man and society, we must take into account that individual deviations can later become collective in the interests of our purposeful work to improve the educational system. 
Culturally acceptable deviations include genius, heroic action, achievements in sports, and leadership skills. Culturally unacceptable deviations include patterns of social behavior that are detrimental to the individual and society and are condemned by members of society [17, 185-191]. If we look at the causes of deviations, we can see that in terms of functionality, education has not performed its functions adequately. Therefore, such deviations have been and are being fought. However, in such actions aimed at different deviations, care must be taken to avoid giving in to feelings and opinions, and to relate cause and effect. After all, it is known from the science of psychology that not every person can have the same and equal level of expression of emotional culture, way of thinking or exemplary behavior [7]. This, in turn, requires educating the younger generation with a sense of respect for national traditions, customs, values, memory, in short, national history. After all, as Karimov said, "Self-awareness begins with knowing history" [4, 14]. Knowledge of history is the main basis for understanding national interests, as well as expressing feelings such as national pride, national affiliation, national honor and pride, national unity. Therefore, in educating young people in the spirit of protection of national interests, it is expedient to take into account the following factors:

- The connection of psychological processes with the practical activities of young people and real socio-economic and cultural factors;

- The principle of history, the individual consciousness of young people, the integral connection of their psychological state with the system of culture, language, symbols (L. Vygotsky) [18, 379];

- To look at young people as an active force in self-awareness, to take into account "their activity in relation to the environment" (M. Basov) [7];
- That consciousness is only manifested, formed in the process of activity ( $\mathrm{S}$. Rubinstein) [9];

- The connection of practical activity with mental activity (A. Leontev) [6, 102-107] requires consideration.

This system of scientific views requires special attention to the functional-structural aspects of the use of educational methods in practice $[2,108]$. This in turn encourages us to know the history of the method of upbringing. Although upbringing has developed uniquely in each region in terms of functionality, [1] it has been studied in relation to the childhood history of mankind. For example, the French Researcher $\mathrm{L}$. Demos studied the whole history of childhood and divided them into six stages in terms of historical periodicity, in terms of the method of their upbringing, more precisely, the idea, purpose, structure of the method of upbringing. These are: - methods such as infanticide, waiver, ambivalence, binding, socializing and supportive.

If we analyze these concepts, it will be possible to determine at the heart of each concept the method of raising children and the way parents interact with their children ("proximity and distance" in terms of social distance). In fact, there is a definite distance between any object, event, and event, not only between people. It is this distance that determines the structure of an object, the occurrence of an event or phenomenon, and the cause and nature of social relations. In this case, the distance determines the level of perception of the object. Distance is necessary to ensure the smooth flow of interpersonal relationships. However, not everyone can determine exactly how to define it, in what order to proceed.

According to the "point of proximity and distance" of distance can be divided into distance between father and mother (husband and wife), distance between parents and children, distance between 
brothers and sisters, distance between grandchildren and grandparents. Each type of distance has a clear meaning in terms of functional structure and is distinguished by its individual components, the essence of which can be observed in the methods of education. For example:

- The infanticide method (covering a historical period from the distant past to the 4th century $A D$ ) has resulted in mass killings of children, with surviving children becoming victims of various forms of violence. As a distant sign of this kind of relationship, we can point to the image of the legendary Medea, a misleading, jealous, vindictive woman.

- The method of renunciation covers the fourth to eighth centuries. Although culturally the infanticide rate has declined since the child was recognized as having a spirit, children remain an object of abandonment for parents. The main means of getting rid of them is to "get rid of" the child, who has been physically destroyed by the caregivers or placed in temples. At the same time, they were kept in the family without being given or abused by a stranger. The distant nature of this method can also be compared to that of the legendary figure Grizelda, who abandoned her children in order to prove her love for her husband.

- The method of ambivalence lasted from the XIV century to the XVII century. It was during this period that parents began to pay attention to children, allowing access to the child's emotional life. They resisted some of the spiritual aspects of their child (feelings, experiences, etc.). If this historical period is considered as a flexible period of the child as a navnikhol, it can be considered from the pedagogical point of view as a type of "character creation". During this period, if a child was disobedient, he was physically pressured and punished in order to prevent arbitrariness. And the same kind of attitude caused them to arouse different emotions (anger, rage, etc.). As a result, a certain pattern of behavior emerged in the child's personality.

- The method of bonding dates back to the eighteenth century, during which time the parents were much closer to the children, but the child in the family was perceived by them as a dangerous object. Because during this period there are cases of children leaving the family. While there are various reasons for this, one of the main reasons may be that these parents seek to control not only their discipline but also their inner world, thinking and will as they take full control of their children. This, in turn, has led to conflict between fathers and children, and we would not be mistaken if we describe these aspects as the period of formation of family relations. After all, any family must be able to perform basic functions. Because their purposeful fulfillment is the basis for a person to understand his worth, to study the essence and meaning of life, the way of life.

- The socialization method lasted until the middle of the XIX and XX centuries, the purpose of education was not only to "conquer" and subdue the child, but also to strengthen his will, to prepare him for future independent life. It can be pointed out that this method of education is related to various theoretical foundations, including some ideas of teachings such as Freudianism, behaviorism, and sociological functionalism. In essence, this method is perceived by parents as an object of socialization, not as a subject of socialization of the child.

The auxiliary method has been in use since the second half of the twentieth century. According to the content of this method, the child, as a parent, must admit that he knows 
what he needs at different stages of his life. Because, "... a person acquires such values as healthy development in the family, selfexpression, and most importantly, the family realizes spiritual creativity" $[15,6]$. In this regard, parents strive to ensure that they mature individually, nurturing them harmoniously and shaping them as individuals. Human maturity is “... a multifaceted and gradual psychological process, the purpose of which depends on the potential of the family (spiritual, economic, intellectual, cultural, etc.)" [10, 200].

Man acquires survival values and selfexpression values in the family. This method is characterized by a positive content compared to other methods because it ensures the emotional closeness of parents to their children, mutual understanding and empathy.

In order to determine the level of significance of the views expressed, an empirical study was conducted on the topic "Study of the mechanism of protection of young people from the effects of destructive information". The study involved 120 parents (of whom: 55 live in the city center, 45 live in the district centers, and 20 parents were selected as a control group). The questionnaire consisted of several parts and examined the subjective perceptions of parents about the method of upbringing in order to comprehensively study the chosen topic. The results were analyzed in the form of a pairwise comparison, and the aggregated data were interpreted based on the content analysis method. The results (Table 1) were studied comparatively divided into two groups according to their content: "Traditional approach to education" and "Innovative approach to education".

\section{RESULT AND DISCUSSION}

In the studied families, although the eastern family relations are established, the religious, national, universal culture formed over the centuries, in all circumstances, they are characterized by the priority of human dignity, based on national morality, family attitudes to the method of upbringing are different. At the same time, based on the review of the results of the applied research, it should be noted that $47.0 \%$ of parents that were surveyed understand the means used to "manage child behavior" as a method of education. Given their perceptions of the method of upbringing, we have shown that it is a traditional approach to the method of upbringing. $51.0 \%$ of parents surveyed said that the method of parenting is "the necessary measures to raise a capable child".

\section{Table 1}

\section{A comparative review of parental attitudes toward parenting methods}

\begin{tabular}{|c|c|c|c|}
\hline S/n. & $\begin{array}{l}\text { Traditional approach to the } \\
\text { method of education }\end{array}$ & S/n. & $\begin{array}{l}\text { A new approach to the method of } \\
\text { education }\end{array}$ \\
\hline 1. & $\begin{array}{l}\text { The method of upbringing is to } \\
\text { manage this child's behavior }\end{array}$ & 1. & $\begin{array}{l}\text { The method of parenting is a way of } \\
\text { determining the necessary measures } \\
\text { for the upbringing of a gifted child }\end{array}$ \\
\hline
\end{tabular}


The American Journal of Social Science and Education Innovations

(ISSN - 2689-100x)

Published: November 30, 2020 | Pages: 568-574

2020: $5 \cdot 525$

Doi: https://doi.org/10.37547/tajssei/Volume02Issue11-98

OCLC - 1121105668

\begin{tabular}{|c|c|c|c|}
\hline 2. & $\begin{array}{c}\text { The method of upbringing is to be } \\
\text { able to understand the behavior } \\
\text { and experiences of this child }\end{array}$ & 2. & $\begin{array}{c}\text { The method of upbringing is a means } \\
\text { of listening to the child }\end{array}$ \\
\hline 3. & $\begin{array}{c}\text { The method of upbringing is to } \\
\text { sacrifice oneself for the future of } \\
\text { these children }\end{array}$ & $3 \cdot$ & $\begin{array}{c}\text { The method of upbringing is a means } \\
\text { by which parents adopt their children } \\
\text { equally }\end{array}$ \\
\hline 4. & $\begin{array}{c}\text { The method of discipline is a } \\
\text { careful approach to the evaluation } \\
\text { of this behavior }\end{array}$ & $4 \cdot$ & $\begin{array}{r}\text { The method of upbringing is a means } \\
\text { of knowing the child's "I" }\end{array}$ \\
\hline 5. & $\begin{array}{c}\text { The method of parenting is to } \\
\text { know the child and determine the } \\
\text { way to influence him }\end{array}$ & $5 \cdot$ & $\begin{array}{c}\text { The method of upbringing is a tool to } \\
\text { take into account that the inner world } \\
\text { of the child is a mystery }\end{array}$ \\
\hline
\end{tabular}

The results show that over the course of history, the method of upbringing has changed in content and improved in terms of ensuring that each family achieves its goals, interests and aspirations. There are several reasons for this improvement:

- First of all, it is the development of science and technology and culture;

- Second, the emergence of various "barriers" to the development of children (imitation, destructive position, subcultures, religious movements, destructive ideas and the dissemination of dangerous information, etc.);

- Thirdly, the ineffectiveness of the approach with a limited set of measures to the method of education is determined by the lessons of domestic and social life;

- Fourthly, the content of family education has improved in the following ways:

- strengthening national unity, ensuring the priority of national interests and understanding of the responsibility of each of our compatriots to their nation;
- respect and attention to all nationalities and ethnic groups living in our country,

helping them to master the state language, national traditions, customs and values, providing them with ample opportunities for the development of their national culture.

\section{CONCLUSION}

Therefore, shaping the knowledge of parents on the upbringing of children on the basis of the protection of our national interests, "Tasks and types of education", "How do you choose methods of education?" It is advisable to provide information on topics such as practical importance for the development of harmoniously developed youth, which will improve our national development.

\section{REFERENCES}

1. Askarova O., Hayitboev M. History of education / textbook. - T., TDPU, 2003. 
2. Belyaeva L.A. Philosophy of education as the basis of pedagogical activity. - Ekaterinburg, 1993. - P. 108.

3. Karimov I.A. High spirituality is an invincible force. - Tashkent: Manaviyat, 2008.

4. Karimov. I.A. There is no future without historical memory. Tashkent: Shark, 1998. P.14.

5. Korostyleva L. A. Problems of selfrealization of personality in the system of human science / Psychological problems of selfrealization of personality / Under ed. L. A. Korostylevoy. - SPb., 1997.

6. Leontiev A.N. Activity. Consciousness. Personality. - M., 1975. - P.102-107.

7. Nepomnyashchaya N.I. Psychodiagnostics of personality: Theory and practice / Textbook. manual for stud. universities. - M., 2001.

8. Proceedings of the International scientific-practical conference "Healthy family - the basis of a healthy society" / Tashkent: - 2012.

9. Rubinstein S.L. General psychology problems. - M., 1973.

10. Samarov R.S. Human maturity and social environment (on the example of the family) / Proceedings of the international scientific-practical conference "Healthy family - the basis of a healthy society" / T., - 2012. p.200.

11. Shibutani T. Social psychology. - M., 2000., Kravchenko A.I. Sociology I Textbook. - M., Yekaterinburg, 2000.

12. Simonenko T.I. The concept of education in hermeneutic experience I J. Bulletin of St. Petersburg University. Series 6, issue 3, 2010.

13. The Constitution of the Republic of Uzbekistan. - T.: Uzbekistan, NMIU, 2014.

14. The perfection of our youth is our future happiness. / Magazine "For a healthy generation" / Tashkent: - 2013
15. The perfection of our youth is our future happiness. / Magazine "For a Healthy Generation" / Issue 2, February 2013. Tashkent. - Page 6.

16. Vodopyanova N.E. Professional burnout and resources to overcome it / Psychology of health / Ed. G. S. Nikiforov. - SPb., 2003.

17. Volkov Yu.G., Mostovaya I.V. Sociology. - M., 1998. - P. 185-191.

18. Vygotsky L.S. Selected Psychological Research. - M., 1956. - P. 379. 